\title{
科研直読式ポケット線量計によるX線装置エネルギーの検討
}

\author{
国立松戸療養所（所長 近藤通六） \\ 喜多義 雄 \\ （論交受付 昭和 33 年 8 月 4 日）
}

\section{EXAMINATION OF ENERGY OF X-RAY APPARATUS WITH A - POCKET CHAMBER DEVISED BY THE INSTITUTE OF SCIENTIFIC MEASUREMENTS}

By Yoshio KITA

Matsudo National Sanatorium.

(Director : MICHIROKU KONDO)

(Article recieved : Augast 4, 1958)

\section{Summary}

$\mathrm{X}$-ray apparatus is generally operated from control panel with the various measurements. None of them, however, is completely accurate and the peculiarities of each apparatus cause an error when the voltage is changed. Therefore, the author measured radiant energy directly with a pocket chamber; when compared with the results of indirect measuring, the difference was difinite ahd this direct method gave a more accurate count of radiant energy.

\section{緒言}

$\mathrm{X}$ 線照射線量の式は蹦床的に $E=K \cdot 1 \mathrm{~V}^{2} Z / D^{2} \cdot T$ と なりこの式を使ってわれわれは日常装置を作動させてい る、しかしこの式の通りにX線装置からエネルギーを放 射しているか否かは甚だ疑問である.何故ならばX線䒾 置の出力はその機器に加えられた入力電圧, 計器類の精 密度並びに装置の新，旧，設備の良否などに深く関係す るからである。

そこで私は装置の出力を綜合的に検討するために線量 計を用い曝射線量が制御卓子上の諸計器と如何なる関倸 にあるかを研究した。

なお実験の本装置は昭和17年製でその後数回修理す加 えていろので，最新式の装置よりみれば甚だ旧型に属し 精度は多少危ぶまれるが，現在なお主要装置として活動 しているのでその特性を検討した。

\section{実 験 寸 法}

使用X線装置．後藤風雲堂ツートヘリオポス 500MA 型,管球 SDR - 6kW, 科研ポケット型線量計 No. 530630 . 管球焦点一線量計間距離 $175 \mathrm{~cm}$, 佅上 $150 \mathrm{~cm}$, 照射野の 直径 $11.5 \mathrm{~cm}$, 長さ $16 \mathrm{~cm}$, 電源電圧の昇降には出力 15
kVA Auto Transformer. を使用した。

曝射線量の测定は 3 回でその平均值をとった。

\section{実験成績並びに考察}

\section{1）各管写压における X線管加熱電圧の变化と晿射線 兵の罚保}

SDR $6 \mathrm{~kW}$ 管球の加熱電圧を $60,65,70,75 \mathrm{~V}$ と変元 て各管電圧時の曝射線量を測定すると，どの管電圧でも 加熱電圧 $70 \mathrm{~V}$ までは MAS メータ一の指示及び線量は 共に増加する.75V になると MAS の増大に反し曝射線 量沬逆に減少する。しかしいずれの管電王においてる線

\begin{tabular}{|c|c|c|c|c|c|c|c|c|c|c|}
\hline \multirow{2}{*}{$\begin{array}{l}\text { teE } \\
\text { KVP }\end{array}$} & \multirow{2}{*}{$\begin{array}{l}\text { 淂 } \\
\text { SEC }\end{array}$} & \multirow{2}{*}{$\begin{array}{c}x+2 \\
v \\
\text { mere }\end{array}$} & \multirow[b]{2}{*}{ MAs } & \multirow{2}{*}{ 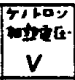 } & \multicolumn{6}{|c|}{ 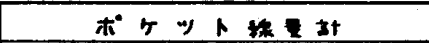 } \\
\hline & & & & & gentz & 8 & $\mathbf{3 1}$ & 78 & PE年 & $M r$ \\
\hline 49 & 0.1 & 60. & 14 & 75 & -10 & 19 & $g$ & & & \\
\hline 50.5 & - & * & 13 & - & & 28 & , & g & 0.36 & 3.24 \\
\hline 50.5 & - & 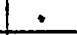 & - & 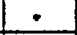 & & 37 & + & & & \\
\hline 51 & - & 65 & 20 & - & & 50 & 13 & & & \\
\hline 50.5 & - & - & 18 & + & & 60 & 10 & 12 & 0.36 & 4.32 \\
\hline 50.5 & - & - & 20 & - & & 73 & 13 & & & \\
\hline - & + & 70 & $30^{\circ}$ & - & & 87 & 14 & & & \\
\hline$\bullet$ & $\cdot$ & - & 31 & $\cdot$ & & 100 & 13 & 14 & 0.36 & 5.04 \\
\hline 51 & - & - & - & 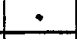 & & 115 & 15 & & & \\
\hline - & 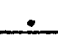 & 75 & 40 & - & & 126 & 11 & & & \\
\hline 50 & - & . & 41 & + & & 138 & 12 & 11 & 0.36 & 3.96 \\
\hline 50.5 & - & . & 39 & - & & 148 & 10 & & & \\
\hline
\end{tabular}


量曲線は山形になり $70 \mathrm{~V}$ 付近で最高の|X|線量を示して いる.

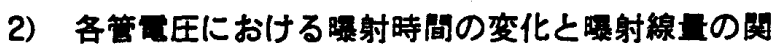
保

\begin{tabular}{|c|c|c|c|c|c|c|c|c|c|c|}
\hline \multirow{2}{*}{$\begin{array}{l}\text { Ser. } \\
\text { KVP }\end{array}$} & \multicolumn{2}{|c|}{ 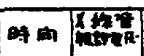 } & \multirow{2}{*}{\multicolumn{2}{|c|}{ MAS }} & \multicolumn{6}{|c|}{ 柠厅 } \\
\hline & SEC & $v$ & & & 0104tex & 且 & ह 5 & $F \pm n$ & A正平 & $M r$ \\
\hline 60 & 0.1 & 60 & 14 & 75 & -12 & 26 & 14 & & & \\
\hline 59 & - & & 13 &. & & 40 & 14 & 13.7 & 0.36 & 4.94 \\
\hline 60 & - & & 14 & 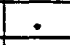 & & 57 & 13 & & & \\
\hline 60.5 & - & 65 & 20 & $\dot{-}$ & -132 & 156 & 24 & & & \\
\hline 59.5 & $\dot{\square}$ & $\cdot$ & $\cdot$ & $\dot{-}$ & & 177 & 19 & 20 & 0.36 & 7.2 \\
\hline 60 & $\dot{-}$ & - & 21 & $\cdot$ & -12 & 30 & 18 & & & \\
\hline 59.5 & 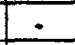 & 70 & 31 & , & & 52 & 22 & & & \\
\hline - & - & $\bullet$ & $\bullet$ & $\dot{-}$ & & 74 & $\div$ & 22 & 0.36 & 7.92 \\
\hline+ & 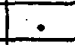 & & 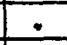 & $\because$ & & 96 & $\dot{-}$ & & & \\
\hline$\dot{\circ}$ & - & 75 & 36 & $\therefore$ & & 114 & 18 & & & \\
\hline$\cdot$ & $\div$ & - & 39 & $\cdot$ & & 132 & - & 18.7 & 0.36 & 6.73 \\
\hline 61 & - & $\therefore$ & 40 & + & & 152 & 20 & & & \\
\hline
\end{tabular}
$\times 4$

\begin{tabular}{|c|c|c|c|c|c|c|c|c|c|c|}
\hline E. & 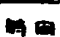 & $8 \%$ & & $7+00$ & & $\overline{木^{\circ},}$ & $\infty$ & 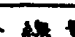 & 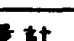 & \\
\hline KVP & BEC & $v$ & MAS & $v$ & gegkz & 日昷 & 131 & $\rightarrow \infty$ & $4 \pm$ & $\mathrm{Mr}$ \\
\hline 79 & 0.1 & 60 & 16 & 75 & -8 & 37 & -29 & & & \\
\hline & & $\bullet$ & - & $\dot{-}$ & & 68 & 31 & 30.7 & 0.38 & 11.66 \\
\hline- & • & - & 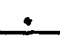 & - & & 100 & 32 & & & \\
\hline 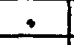 & 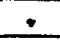 & 65 & 27 & $\therefore$ & & 147 & 47 & & & \\
\hline . & - & - & 25 & - & & 190 & 43 & 44.3 & 0.38 & 1683 \\
\hline 82 & $\dot{\square}$ &. & $\cdot$ & 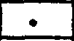 & -7 & 50 & $\cdot$ & & & \\
\hline 81.5 & $\bullet$ & 70 & 35 & - & & 98 & 48 & & & \\
\hline 81 & $\cdot$ & $\therefore$ & • & - & & 150 & 52 & 47.5 & 0.38 & 18.05 \\
\hline 78.5 & $\dot{1}$ & $\circ$ & 32 & - & -10 & 53 & 43 & & & \\
\hline 81.5 & $\cdot$ & 75 & 44 & 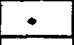 & & 90 & 37 & & & \\
\hline 81 & $\dot{\bullet}$ & $\cdot$ & 42 & 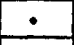 & & 122 & 32 & 34.6 & 0.38 & 13.08 \\
\hline 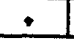 & $\div$ & $\cdot$ & 46 & 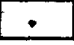 & & 157 & 35 & & & \\
\hline
\end{tabular}

\begin{tabular}{|c|c|c|c|c|c|c|c|c|c|c|}
\hline & & & & & & & $\Rightarrow$ & 14 & $8 t$ & \\
\hline & KYP & SEC & $y$ & MAS & BIth & 10 & (K) & $4 x$ & 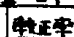 & $M r$ \\
\hline 02 & 49.5 & 0.1 & 70 & 29 & -10 & 20 & 10 & & & \\
\hline$\leftarrow$ & 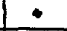 & $\bullet$ & $\bullet$ & $\bullet$ & & 30 & + & 10 & 0.36 & 3.6 \\
\hline 98 & $\dot{-}$ & $\cdot$ & - & $\circ$ & & 40 & $\cdot$ & & & \\
\hline$\cdot$ & 49 & 0.2 & $\bullet$ & 43 & & 57 & 17 & & & \\
\hline- & 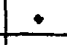 & $\therefore$ & - & 44 & & 74 & $\bullet$ & 17.5 & 0.36 & 6.3 \\
\hline 97 & 50.5 & - & $\dot{-}$ & 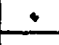 & & 93 & 19 & & & \\
\hline$\therefore$ & 50 & \begin{tabular}{|l}
0.3 \\
\end{tabular} & - & 62 & & 122 & 29 & & & \\
\hline 100 & $\cdot$ & $\cdot$ & - & $\cdot$ & & 150 & 28 & 29 & 0.36 & 10.4 \\
\hline & 50.5 &. & $\cdot$ & 58 & & 180 & 30 & & & \\
\hline
\end{tabular}

\begin{tabular}{|c|c|c|c|c|c|c|c|c|c|c|}
\hline \multirow{2}{*}{ 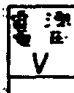 } & \multirow{2}{*}{$\begin{array}{l}\text { Trex } \\
\text { KYP }\end{array}$} & \multirow{2}{*}{\multicolumn{2}{|c|}{ 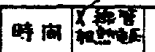 }} & \multirow[b]{2}{*}{ MAS } & \multicolumn{6}{|c|}{ 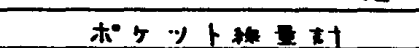 } \\
\hline & & & & & $\overline{\text { Begetze }}$ & 80 & 831 & $x$ & 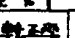 & $M r$ \\
\hline 1.0 .1 & 60 & 0.1 & 70 & 27 & -17 & 24 & 15 & & & \\
\hline & $\cdot$ & & $\cdot$ & - & & 42 & 18 & 17 & 0.36 & 6.14 \\
\hline- & - & $\bullet$ & 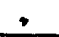 & $\cdot$ & & 60 & $\cdot$ & & & \\
\hline$\div$ & $\dot{-}$ & 0.2 & - & 45 & & 93 & 33 & & & \\
\hline- & - & - & - & 46 & & 130 & 43 & 36 & a36 & 12.9 \\
\hline 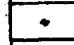 & $\div$ & - & $\div$ & $\div$ & & 163 & 33 & & & \\
\hline$\cdot$ & - & 0.3 & - & 62 & -10 & 55 & 45 & & & \\
\hline$\cdot$ & $\cdot$ & & $\cdot$ & $\cdot$ & & 104 & 49 & 48 & 0.36 & 17.5 \\
\hline$\bullet$ & 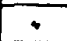 & - & - & 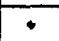 & & 154 & 50 & & & \\
\hline
\end{tabular}

\begin{tabular}{|c|c|c|c|c|c|c|c|c|c|c|}
\hline \multirow{2}{*}{$\begin{array}{l}8 \text { EEF } \\
\text { KVP } \\
\end{array}$} & \multirow{2}{*}{$\begin{array}{l}\text { min } \\
\text { SEEC }\end{array}$} & \multirow{2}{*}{ 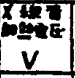 } & \multirow[b]{2}{*}{ Mas } & \multirow{2}{*}{ 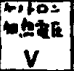 } & \multicolumn{6}{|c|}{ 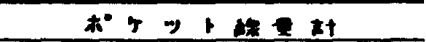 } \\
\hline & & & & & Bom & an & \&21 & 平地 & HEx & $M r$ \\
\hline 69 & 0.1 & 60 & 13 & 75 & -120 & 144 & 24 & & & \\
\hline 69.5 & $\cdot$ & & 14 & $\cdot$ & & 169 & 25 & 23 & 0.36 & 0.3 \\
\hline 69 & $\dot{-}$ & $\dot{-}$ & 12 & $\dot{-}$ & & 190 & 21 & & & \\
\hline 70.5 & - & 65 & 22 & $\cdot$ & -10 & 45 & 35 & & & \\
\hline 70 & $\dot{-}$ & $\bullet$ & 22 & $\bullet$ & & 77 & 32 & 33 & 0.36 & 111.9 \\
\hline 69.5 & - & . & 21 & - & & 110 & 33 & & & \\
\hline 70.5 & - & 70 & 28 & - & & 146 & 36 & & & \\
\hline 70 & . & $\bullet$ & 29 & $\bullet$ & & 180 & 34 & 34 & 0.36 & | 13.24 \\
\hline 71 & - & 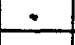 & 28 & 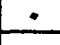 & -8 & 40 & 32 & & & \\
\hline 68.5 & $\cdot$ & 75 & 37 & - & & 67 & 27 & & & \\
\hline$\cdot$ & $\cdot$ & • & 34 & $\dot{-}$ & & 90 & 23 & 27 & 036 & 9.7 \\
\hline 69 & - & $\cdot$ & - & - & & 120 & 30 & & & \\
\hline
\end{tabular}

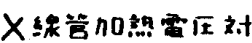
$\times 5$ 宣它压綡重曲综

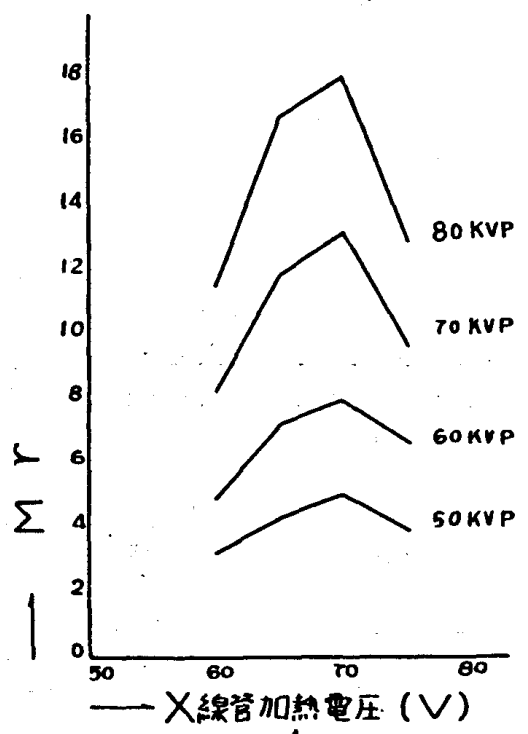

T3

\begin{tabular}{|c|c|c|c|c|c|c|c|c|c|c|}
\hline 而 & 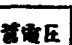 & 事息 & $\mathrm{CST}^{2}$ & & & t。 & 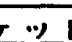 & . & t & \\
\hline v & KVP & SEC & $\mathrm{v}$ & MAs & Irithe & 16 & 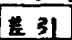 & 平均 & An & $M r$ \\
\hline 98 & 60.5 & 0.1 & 70 & 33 & -57 & 94 & 3.7 & & & \\
\hline 100 & 70. & $\cdot$ & $*$ & 29 & & 130 & 36 & 34 & 0.36 & 12.2 \\
\hline 97 & 69.5 & $\bullet$ & ? & 28 & & 160 & 30 & & & \\
\hline 99 & 70.5 & 0.2 & . & 43 & -5 & 54 & 40 & & & \\
\hline 100 & 70. & - & - & 46 & & 107 & 53. & 52 & 0.36 & 18.7 \\
\hline$\bullet$ & , & 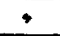 & - & 43 & & 160 & $\bullet$ & & & \\
\hline 98 & 69.5 & 0.3 & ? & 60 & -13 & 82 & 69 & & & \\
\hline 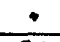 & - & . & • & 64 & & 160 & 78 & 73 & 0.36 & 26.25 \\
\hline 99 & 70 & , & - & 63 & -12 & 84 & 72 & & & \\
\hline
\end{tabular}

T4

\begin{tabular}{|c|c|c|c|c|c|c|c|c|c|c|}
\hline \multirow{2}{*}{ 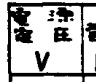 } & \multirow{2}{*}{$\begin{array}{l}5,1 \times \\
\text { KYP } \\
\end{array}$} & \multirow{2}{*}{$\begin{array}{l}\text { 解 } \\
\text { SEC }\end{array}$} & \multirow{2}{*}{ 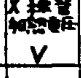 } & \multirow[b]{2}{*}{ MAS } & \multicolumn{6}{|c|}{ ポント 杜 } \\
\hline & & & & & Bespont & Q0. & 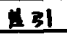 & \#负 & & $M r$ \\
\hline 99 & 81.5 & 0.1 & 70 & $2 \dot{8}$ & -85 & 133 & 48 & & & \\
\hline 97 & 80.5 & $\cdot$ & 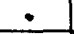 & 27 & & 177 & 44 & 46 & 0.38 & 17.4 \\
\hline 100 & 80 & 3 & - & 29 & -9 & 54 & 45 & & & \\
\hline 101 &. & 02 & - & 44 & & 128 & 74 & & & \\
\hline$\cdot$ & $\cdot$ & $\cdot$ & 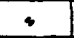 & 43 & & 200 & 72 & 73 & 0.38 & 7 \\
\hline 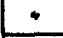 & 80.5 & $\dot{-}$ & - & 44 & -6 & 78 & 72 & & & \\
\hline$\cdot$ & - & 0.3 & - & 61 & & 188 & 110 & & & \\
\hline - & $\bullet$ & - & $\bullet$ & 60 & -6 & 108 & 102 & 105 & 0.38 & 40. \\
\hline . & - & • & $\bullet$ & 62 & -6 & 110 & 104 & & & \\
\hline
\end{tabular}


電源電圧を $100 \mathrm{~V}$ 亿保ち上記の実験よりX線管加熱電 王を70V一定にし，各管電圧において，時間を $0.1 ， 0.2$ ， 0,3 秒と変えて曝射線量を測定した。管電圧 $50 \mathrm{kVp}$ 及び $60 \mathrm{kVp}$ までは曝射時間に比例して線量は増加するが, 70 $\mathrm{kVp}$ 並びに $80 \mathrm{kVp}$ では時間を 0.1 秒から 3 倍の 0.3 秒 に延しても線量ははば 2 倍にしか增加していない.

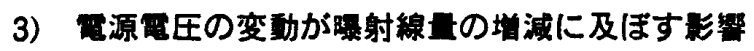

$\mathrm{X}$ 線装置の入力電纴を $80 \mathrm{~V}$ より $107 \mathrm{~V}$ まで変えて X

\begin{tabular}{|c|c|c|c|c|c|c|c|c|c|c|}
\hline \multirow{2}{*}{ 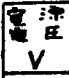 } & \multirow{2}{*}{$\begin{array}{l}\text { TQE } \\
\text { KVP } \\
\end{array}$} & \multirow{2}{*}{$\begin{array}{l}\text { (1) } \\
\text { SEC }\end{array}$} & \multirow{2}{*}{$\begin{array}{c}x=8 \\
x \\
x=2\end{array}$} & \multirow[b]{2}{*}{ MAS } & \multicolumn{6}{|c|}{ 車, } \\
\hline & & & & & 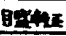 & 目是 & 251 & F⿻二丨 & 徒体 & $M r$ \\
\hline 99 & 90 & 0.1 & 70 & 28 & -10 & 64 & 54 & & & \\
\hline$\cdot$ & - & " & - & 27 & & 117 & 53 & 55 & 0.4 & 22 \\
\hline 98 & 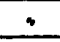 & - & + & 30 & & 174 & 5.7 & & & \\
\hline 99 & 91 & 0.2 & - & 40 & -9 & 87 & 78 & & & \\
\hline 100 & - & 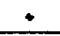 & - & + & & 173 & 86 & 81 & 0.4 & 32.4 \\
\hline+ & - & - & - & - & -10 & 89 & 79 & & & \\
\hline & & & & & & & & & & \\
\hline & & & & & & & & & & \\
\hline & & & & & & & & & & \\
\hline
\end{tabular}

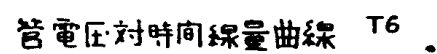

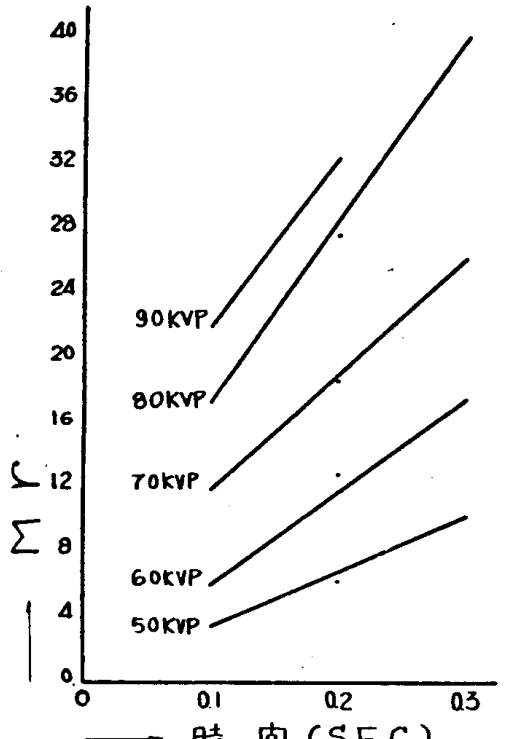

時间 (SEC)
線管加熱電圧 $70 \mathrm{~V}$. 整流管加熱電圧 $75 \mathrm{~V}$. 管電圧 $75 \mathrm{kVp}$ 曝射時間を 0.1 及び 0.2 秒にして線量を測定すると電源 電圧の上昇にともない MAS が僅かに变化するが線量は 大巾に増加する.図表中破線で示すのは管電圧 $60 \mathrm{kVp} の$ 線量である。

\begin{tabular}{|c|c|c|c|c|c|c|c|c|c|c|}
\hline \multirow{2}{*}{$\begin{array}{l}V^{3} \\
V^{3}\end{array}$} & \multirow{2}{*}{$\begin{array}{l}\text { reE } \\
\text { KVP }\end{array}$} & \multirow{2}{*}{$\begin{array}{l}\text { 的 im } \\
\text { SEC }\end{array}$} & \multirow{2}{*}{$\begin{array}{c}x y \\
V \\
y\end{array}$} & \multirow{2}{*}{ MAs } & \multicolumn{6}{|c|}{ ネ•ケット } \\
\hline & & & & & $8 e^{2}+x^{2}$ & 80 & 31 & ₹4t & $4=0$ & $M r$ \\
\hline 80 & 69.5 & 0.2 & 70 & 49 & -47 & 87 & 40 & & & \\
\hline+ & 4 & $\bullet$ & - & 48 & & 128 & 41 & 41 & 0.36 & 14.8 \\
\hline+ & - & - & $\cdot$ & 50 & & 170 & 42 & & & \\
\hline 89 & 70 & $\cdot$ & $\bullet$ & 52 & -22 & 67 & 45 & & & \\
\hline - & $\bullet$ & 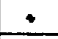 & $\cdot$ & 54 & & 114 & 47 & 45 & 0.36 & 16.2 \\
\hline - & 69.5 & - & + & 52 & & 163 & 49 & & & \\
\hline 101 & $\cdot$ & $\stackrel{+}{+}$ & $\cdot$ & 54 & -18 & 67 & + & & & \\
\hline 4 & 71 & + & $\cdot$ & 50 & & 124 & 57 & 53 & 0.36 & 19.3 \\
\hline 102 & 69 & - & $\cdot$ & 53. & & 177 & 53 & & & \\
\hline 106 & 70 & $\bullet$ & • & 55 & -20 & 74 & 54 & & & \\
\hline - & • & - & - & + & & 134 & 60 & 57.2 & 0.36 & 20.6 \\
\hline - & - & . & . & . & & 192 & 58 & & & \\
\hline
\end{tabular}

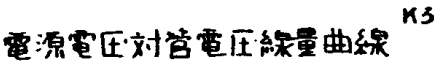

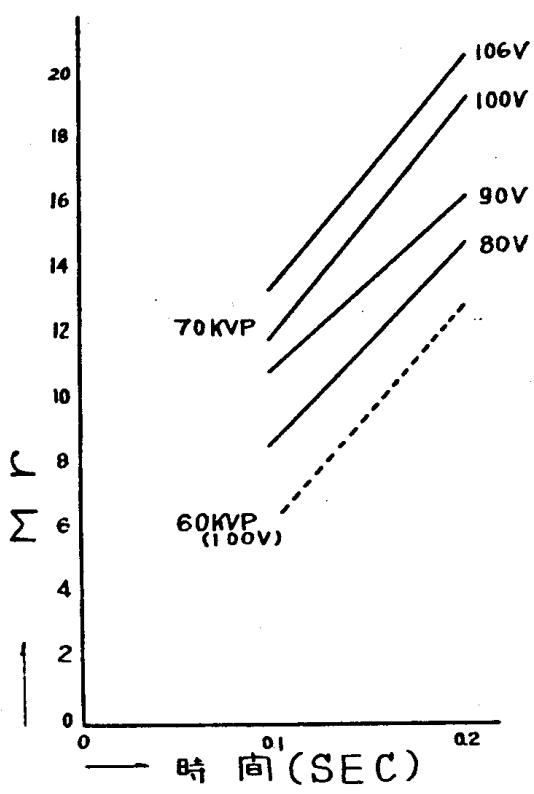

\begin{tabular}{|c|c|c|c|c|c|c|c|c|c|c|}
\hline \multirow{2}{*}{$\begin{array}{l}\text { 震 } \\
v \\
\end{array}$} & \multirow{2}{*}{$\begin{array}{l}\text { KVP } \\
\text { KVP }\end{array}$} & \multirow{2}{*}{$\begin{array}{l}\text { 和 } \\
\text { SEC }\end{array}$} & \multirow{2}{*}{$\begin{array}{c}x, y=0 \\
v\end{array}$} & \multirow[b]{2}{*}{ MAS } & \multicolumn{6}{|c|}{ 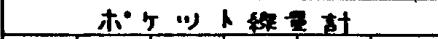 } \\
\hline & & & & & 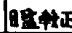 & Ex & स्रा & 平坞 & 怔理 & $M r$ \\
\hline 80 & 70 & 0.1 & 60 & 16 & -10 & 35 & 25 & & & \\
\hline+ & + & - & $\cdot$ & 15 & & 53 & 18 & 21 & 0.36 & 7.56 \\
\hline - & + & + & - & - & & 73 & 20 & & & \\
\hline 81 & - & - & 65 & 23 & & 100 & 27 & & & \\
\hline - & • & - & $\bullet$ & 25 & & 126 & 26 & 27 & 0.36 & 9.7 \\
\hline$*$ & 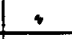 & - & 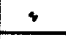 & - & & 154 & 28 & & & \\
\hline 8 & + & - & 70 & 32 & -37 & 60 & 23 & & & \\
\hline - & 71 & - & - & + & & 84 & 24 & 23 & 0.36 & 8.37 \\
\hline- & 70.5 & - & - & 29 & & 106 & 22 & & & \\
\hline 82 & 72 & - & 75 & 39 & & 122 & 16 & & & \\
\hline- & 71 & $\cdot$ & - & 38 & & 137 & 15 & 15.3 & 0.36 & 5.5 \\
\hline- & 70.5 & - & - & 40 & & 152 & & & & \\
\hline
\end{tabular}




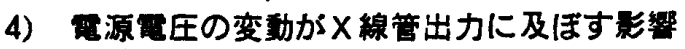

X線管出力が電源電圧の変動に伴ない変化して来る。 すなわち電源電圧を $80,90,100 \mathrm{~V}$ にして曝射時間 0.1 秒管電生 $70 \mathrm{kVp}$ 整流管加熱電圧を $75 \mathrm{~V}$ とし X線管加熱 電纴を変化させると, 電圧 $100 \mathrm{~V}$ のと曝射線量は正常 な形を表わすが，電源が 90 並びに80 Vに降ると曝射線量 の最高值が線管加熱電圧 $65 \mathrm{~V}$ 付近に移ってゆく．すな わち MASの増加は必ずしも線量の増加を意味しない。

\begin{tabular}{|c|c|c|c|c|c|c|c|c|c|c|}
\hline \multirow{3}{*}{$v_{v}^{T}$} & \multirow{3}{*}{$\begin{array}{l}\text { The } \\
\text { KVP }\end{array}$} & \multirow{3}{*}{$\begin{array}{l}\text { H } \\
\text { SEC }\end{array}$} & \multirow{3}{*}{ 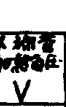 } & \multirow[b]{3}{*}{ MAS } & & & & & & $A 2$ \\
\hline & & & & & \multicolumn{6}{|c|}{ 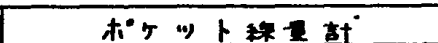 } \\
\hline & & & & & Dit4t & 旦㝵 & 131 & 平坞 & 14i正 & $M r$ \\
\hline 90 & 70 & 0.1 & 60 & 16 & -18 & 42 & 24 & & & \\
\hline$\because$ & 70.5 & - & - & 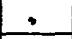 & & 68 & 26 & 24.6 & 0.36 & 8.85 \\
\hline 89 & 69.5 & $\circ$ & - & 14 & & 92 & 24 & & & \\
\hline 91 & + & $\bullet$ & 65 & 23 & & 123 & 31 & & & \\
\hline 88 & 70 & $\cdot$ & $\cdot$ & 22 & & 154 & 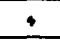 & 31.3 & 0.36 & 11.2 \\
\hline 89 & $\cdot$ & $\cdot$ & $\cdot$ & 24 & & 186 & 32 & & & \\
\hline 91 & 69 & + & 70 & 32 & -10 & 34 & 24 & & & \\
\hline+ & 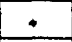 & $\cdot$ & $\therefore$ & 30. & & 60 & 26 & 26.6 & 0.36 & 9.6 \\
\hline 92 & 69.5 & $\cdot$ & + & 32 & & 90 & 30 & & & \\
\hline. & 69 & • & 75 & 40 & & 112 & 22 & & & \\
\hline$\therefore$ & $\cdot$ & - & $\bullet$ & - & & 136 & 24 & 21.6 & 0.36 & 7.78 \\
\hline - & - &. & 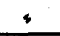 & 38 & & 155 & 19 & & & \\
\hline
\end{tabular}

A3

\begin{tabular}{|c|c|c|c|c|c|c|c|c|c|c|}
\hline \multirow{2}{*}{$\begin{array}{l}V^{35} \\
v\end{array}$} & \multirow{2}{*}{$\begin{array}{l}50 E \\
\text { KVP }\end{array}$} & \multirow{2}{*}{$\begin{array}{l}\text { min } \\
\text { SEC }\end{array}$} & \multirow{2}{*}{$\begin{array}{c}x+2 \\
v \\
v\end{array}$} & \multirow[b]{2}{*}{ MAS } & \multicolumn{6}{|c|}{ 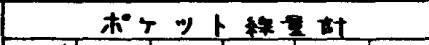 } \\
\hline & & & & & gititi & 6D双 & 53 & 平均 & 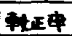 & $M r$ \\
\hline 102 & 69 & 0.1 & 60 & 14 & -13 & 36 & 23 & & & \\
\hline 101 & 71 & 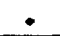 & $\bullet$ & 15 & & 63 & 27 & 25 & 0.36 & 9 \\
\hline 4 & 70.5 & - & $\bullet$ & 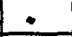 & & 88 & 25 & & & \\
\hline 100 & $\bullet$ & 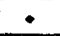 & 65 & 22 & & 124 & 36 & & & \\
\hline . & 70 & $\bullet$ & - & 23 & & 158 & 34 & 34 & 0.36 & 12.2 \\
\hline- & 70.5 & 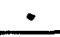 & 4 & 22 & & 190 & 32 & & & \\
\hline - & 71 & - & 70 & 30 & -11 & 44 & 33 & & & \\
\hline 101 & 4 & $\div$ & - & 31 & & 80 & 36 & 35.7 & 0.36 & 12.9 \\
\hline 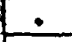 & $\dot{-}$ & 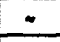 & $\div$ & 32 & & 118 & 38 & & & \\
\hline 100 & 70.5 & . & 75 & 42 & & 147 & 29 & & & \\
\hline - & $\therefore$ & - & - & - & & 175 & 28 & 27.7 & 0.36 & 10 \\
\hline - & 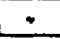 & 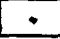 & $\cdot$ & 41 & -8 & 34 & 26 & & & \\
\hline
\end{tabular}

要汿西压刘

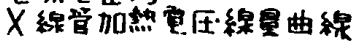

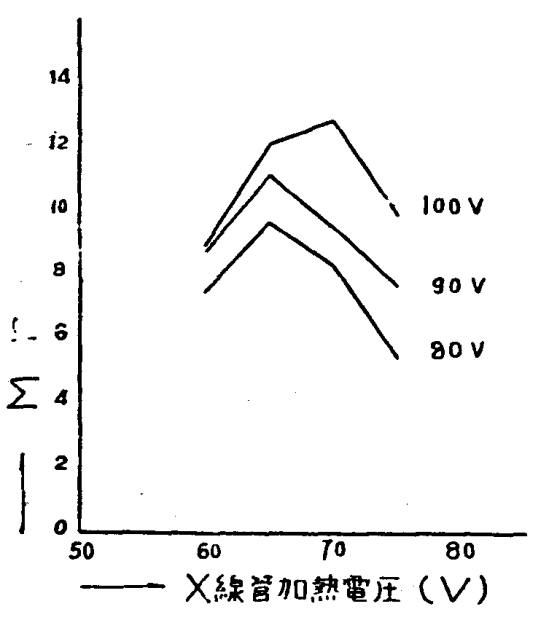

5）篮流管の加熱電圧がX 線管の出力に及ぼす影響

X楾管の出力は整流管の能率に関係することは当然考 えねばならぬ。

そこで私は整流管加熱電圧とX線管出力との関係を夷 験した，先ず管電任 $70 \mathrm{kVp}$ 懪射時間 0.1 秒整流管加熱 電圧を $70,75,80 \mathrm{~V}$ と変えてみると, 整流管電圧 $70 \mathrm{~V}$ においてはX線管出力は甚だしく低下する．75，80Vで は正常の線量曲線を示している。

6) アルミニウムフィルターによる線量の減弱を検討 近時高压撮影に準ずる方法として，アルミニウムフィ ルターを使用して異なる楾貿で撮影する方法が陚みられ

\begin{tabular}{|c|c|c|c|c|c|c|c|c|c|c|}
\hline \multirow{2}{*}{$\begin{array}{c}\text { ropos } \\
v\end{array}$} & \multirow{2}{*}{$\begin{array}{l}\text { KeE } \\
\text { KVP }\end{array}$} & \multirow{2}{*}{$\begin{array}{l}\text { OA } \\
\text { SEC }\end{array}$} & \multirow{2}{*}{ 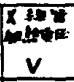 } & \multirow[b]{2}{*}{ MAB } & \multicolumn{6}{|c|}{ 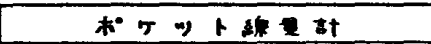 } \\
\hline & & & & & gethis & on & 431 & $7 m$ & $4+27$ & $M r$ \\
\hline 70 & 70 & 0.1 & 60 & 16 & -16 & 38 & 22 & & & \\
\hline 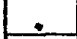 &. & $\bullet$ & + & 15 & & 61 & 23 & 22.7 & 0.36 & 0.1 \\
\hline+ & + & - & + & 14 & & 84 & 23 & & & \\
\hline$\bullet$ & 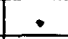 & - & 65 & 25 & & 114 & 30 & & & \\
\hline+ & - & + & - & - & & 144 & 30 & 30.3 & 0.36 & 10.9 \\
\hline- & $\therefore$ & - & + & 24 & & 175 & 31 & & & \\
\hline 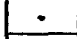 & 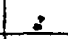 & $\div$ & 70 & 33 & -16 & 36 & 20 & & & \\
\hline$\therefore$ & $\cdot$ & - & - & - & & 57 & 21 & 21.3 & 0.36 & 7.7 \\
\hline$\dot{-}$ & $\cdot$ & 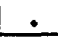 & - & 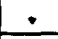 & & 80 & 23 & & & \\
\hline •. & - & . & 75 & 40 & & 90 & 10 & & & \\
\hline. & 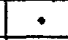 & 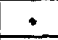 & - &. & & 96 & 8 & 9.3 & 0.36 & 3.35 \\
\hline$\div$ & $\cdot$ &. & $\cdot$ & - & & 100 & 10 & & & \\
\hline
\end{tabular}

L2

\begin{tabular}{|c|c|c|c|c|c|c|c|c|c|c|}
\hline $\begin{array}{l}\text { Fipos } \\
\text { mels }\end{array}$ & \& & 蟙 & $\begin{array}{l}x=2 \\
0 x+1\end{array}$ & & & $\star^{\circ}$ & $\cdots$ & 楼 & $t$ & \\
\hline$v$ & KVP & SEC & $v$ & Mas & octur & B a & 131 & $7 \times 1$ & 선두 & $M r$ \\
\hline 75 & 70 & 0.1 & 60 & 13 & -7 & 30 & 23 & & & \\
\hline$\bullet$ & + & - & - & 14 & & 52 & 22 & 23 & 0.36 & 8.3 \\
\hline- & 69.5 & - & - & 15 & & $76^{\circ}$ & 24 & & & \\
\hline+ & 69 & . & 65 & 22 & & 105 & 29 & & & \\
\hline - &. &. & + & + & & 136 & 31 & 30 & 0.36 & 10.8 \\
\hline - & - & . & - & 23 & & 166 & 30 & & & \\
\hline - &. & . & 70 & 32 & -11 & 42 & 31 & & & \\
\hline - & - & $\cdot$ & - & 33 & & 72 & 30 & 303 & 0.36 & 10.9 \\
\hline 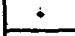 & ro & . & • & 32 & & 102 & - & & & \\
\hline - & 69 &. & 75 & 42 & -10 & 32 & 22 & & & \\
\hline- & . &. & 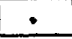 & $\therefore$ & & 54 & \pm & 22.3 & 0.36 & $8 a 2$ \\
\hline - & 71 & เ & - & . & & 77 & 23 & & & \\
\hline
\end{tabular}

LS

\begin{tabular}{|c|c|c|c|c|c|c|c|c|c|c|}
\hline \multirow{2}{*}{ 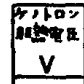 } & \multirow{2}{*}{ 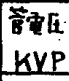 } & \multicolumn{2}{|c|}{ 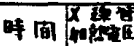 } & \multirow[b]{2}{*}{ MAS } & \multicolumn{6}{|c|}{ 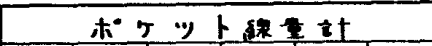 } \\
\hline & & SEC & $v$ & & axton & 回至 & (131 & 平出 & 轨列京 & $M r$ \\
\hline 80 & 70 & 0.1 & 60 & 15 & -15 & 38 & 23 & & & \\
\hline+ & 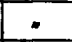 & $\cdot$ & 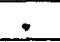 &. & & 62 & 24 & 24 & 0.36 & 8.65 \\
\hline . & ${ }^{\circ}$ & • & * & 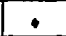 & & 87 & 25 & & & \\
\hline+ & - & 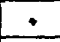 & 65 & 22 & & 118 & 31 & & & \\
\hline$\dot{-}$ & - & $\cdot$ & - & 21 & & 148 & 30 & 31 & 0.36 & 11.2 \\
\hline - & 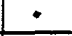 & $\dot{\Delta}$ & 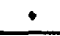 & 23 & & 180 & 32 & & & \\
\hline$\dot{-}$ & 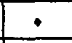 & $\cdot$ & 70 & 30 & -18 & 50 & + & & & \\
\hline . & 70.5 & . & 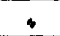 & 32 & & 82 & 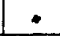 & 33 & 0.36 & 11.8 \\
\hline 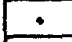 & $\cdot$ & 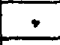 & $\cdot$ & - & & 117 & 35 & & & \\
\hline$\cdot$ & 70 & $\cdot$ & 75 & 42 & & 146 & 29 & & & \\
\hline - & + & $\cdot$ & - & 43 & & 176 & 30 & 29 & 0.36 & 10.45 \\
\hline$\cdot$ & - & $\cdot$ &. & 44 & -12 & 40 & 28 & & & \\
\hline
\end{tabular}


愁流管加热電压凉

X線管加整電庄線量曲線

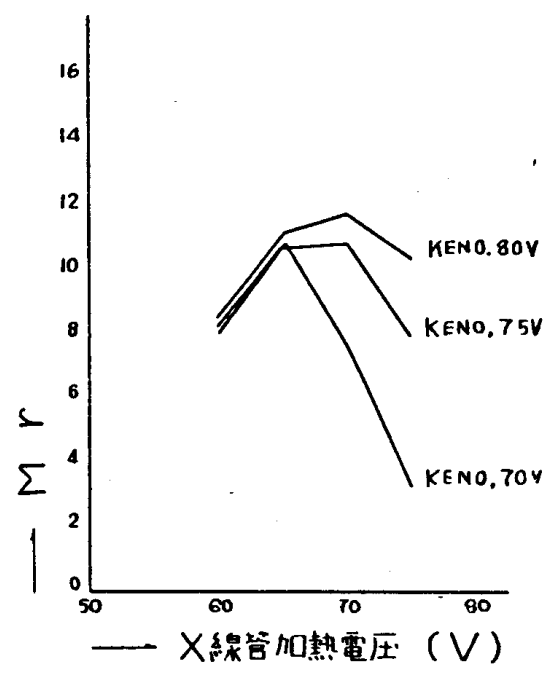

FI

\begin{tabular}{|c|c|c|c|c|c|c|c|c|c|c|}
\hline \multirow{2}{*}{$\begin{array}{l}\text { tot. } \\
\text { KVP }\end{array}$} & \multirow{2}{*}{$\begin{array}{l}\text { 时 } \\
\text { SEC }\end{array}$} & \multirow{2}{*}{ 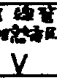 } & \multirow[b]{2}{*}{ MAS } & \multirow{2}{*}{$\begin{array}{l}P_{1<2\}-} \\
A L \\
M / M\end{array}$} & \multicolumn{6}{|c|}{ 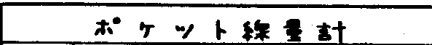 } \\
\hline & & & & & gexhe & 目 & $|-3|$ & 甲均 & +417 & $M r$ \\
\hline 50 & 0.1 & 70 & 34 & 0 & -67 & 82 & 15 & & & \\
\hline 49.5 & + & 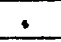 & 35 & 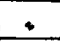 & & 98 & 16 & 16.3 & 0.36 & 5.87 \\
\hline 4 & $\cdot$ &. & 33 &. & & 116 & 18 & & & \\
\hline 49 &. & . & 34 & 0.5 & & 127 & 11 & & & \\
\hline 49.5 & $\cdot$ & $\therefore$ & L33 & 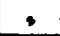 & & 140 & 13 & 11.3 & 0.36 & 4.07 \\
\hline 49 & $\cdot$ &. &. &. & & 150 & 10 & & & \\
\hline - & $\cdot$ & + & 30 & 1.5 & & 156 & 6 & & & \\
\hline$\cdot$ & $\cdot$ & + & 32 & + & & 163 & 7 & 6.6 & 0.36 & 2.36 \\
\hline$\therefore$ & $\cdot$ & $\dot{-}$ & + & + & & 170 & + & & & \\
\hline - & 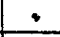 & $\therefore$ & + & 3.0 & & 173 & 3 & & & \\
\hline+ & 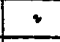 & $\cdot$ & 33 & 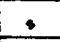 & & 175 & 2 & 2.3 & 0.36 & $0.8 j$ \\
\hline 49.5 & $\cdot$ &. & 32 & . & & 177 & 4 & & & \\
\hline
\end{tabular}

\begin{tabular}{|c|c|c|c|c|c|c|c|c|c|c|}
\hline \multirow{2}{*}{ 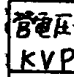 } & \multicolumn{2}{|c|}{ 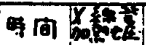 } & \multirow[b]{2}{*}{ MAS } & \multirow{2}{*}{$\begin{array}{l}T_{K L Y-} \\
A L / M \\
M / M\end{array}$} & \multicolumn{6}{|c|}{ ポケット线量邛 } \\
\hline & SEC & $v$ & & & 8>ats & 目武 & स3 & $P \div 7$ & 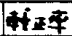 & $M r$ \\
\hline 60.5 & 01 & 70 & 34 & 0 & -7 & 33 & 26 & & & \\
\hline . & - & + & 33 & $\leftarrow$ & & 60 & 27 & 28.3 & 0.36 & 102 \\
\hline- & $\dot{\square}$ & + & 36 & + & & 92 & 32 & & & \\
\hline$\therefore$ & 1 & 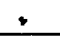 & 35 & 0.5 & & 114 & 22 & & & \\
\hline+ & - &. & 31 & $=$ & & 134 & 20 & 21.6 & 0.36 & 7.78 \\
\hline 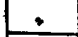 & $\cdot$ & . & 34 & $*$ & & 157 & 23 & & & \\
\hline 61 & - & + & 35 & 1.5 & & 170 & 13 & & & \\
\hline$\div$ & $\div$ & + & + & 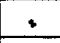 & & 184 & 14 & 12.6 & 0.36 & 4.54 \\
\hline 60.5 & 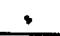 &. & 30 & . & -34 & 45 & 11 & & & \\
\hline. & 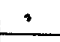 & 3 & 34 & 3.0 & & 52 & 7 & & & \\
\hline - & 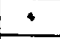 & - & 35 & $\cdot$ & & 60 & 8 & 7.0 & 0.36 & 2.52 \\
\hline 61 & $\cdot$ & . &. & 4 & & 66 & 6 & & & \\
\hline
\end{tabular}

ている.われわれの使用する装置がいくらの線量を昹射 しているかは本実験で詳らかになったので。さらに本測 定值にアルミニウムフィルターを併用しその線量の咸弱 を実験した， no filter. $0.5,1.5,3.0 \%$ とフィルターの

厚さを増してゆ人と線量仗図表の通り減弱する。

故に私は胸部撮影条件(胸厚 $18 \mathrm{~cm} 72 \mathrm{kVp}$ 距離 $175 \mathrm{~cm}$ 極光 FS 時間 0.1 秒フィルター $\mathrm{Al} 0.5 \% \mathrm{~m}$ 線量 12.8

\begin{tabular}{|c|c|c|c|c|c|c|c|c|c|c|}
\hline \multirow{3}{*}{$\begin{array}{l}\text { KeE } \\
\text { KVP }\end{array}$} & \multirow{3}{*}{$\begin{array}{l}\text { of } \\
\text { SEC }\end{array}$} & \multirow{3}{*}{ 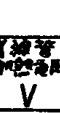 } & \multirow[b]{3}{*}{ MAS } & \multirow{3}{*}{ 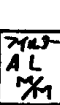 } & & & & & & F3 \\
\hline & & & & & \multicolumn{6}{|c|}{ 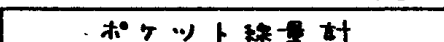 } \\
\hline & & & & & 10\%好 & 目 全 & 引 & רז & 怔㙔 & $M r$ \\
\hline 69 & 0.1 & 70 & 36 & 0 & -5 & 45 & 40 & & & \\
\hline 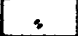 & . & , & 35 & . & & 88 & 43 & 43 & 0.36 & 15.45 \\
\hline$\cdot$ & - &. & . &. & & 134 & 46 & & & \\
\hline 69.5 & $\dot{-}$ & $\because$ & 32 & 0.5 & & 165 & 31 & & & \\
\hline . & $\cdot$ & 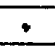 & 35 & 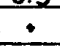 & & 197 & 32 & 32.3 & 0.36 & 11.62 \\
\hline 71 & 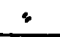 & - & - & $\cdot$ & -7 & 41 & 34 & & & \\
\hline 69.5 & 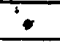 & $\cdot$ & 32 & 1.5 & & 60 & 19 & & & \\
\hline 71 & + & + & 36 & $\because$ & & 85 & 25 & 21.3 & 0.36 & 7.7 \\
\hline 69 & 3 & $\cdot$ & 35 & $\div$ & & 105 & 20 & & & \\
\hline 69.5 & + & 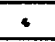 & 34 & 3.0 & & 120 & 15 & & & \\
\hline. & 5 & $\cdot$ & 36 & 2 & & 132 & 12 & 13.3 & 0.36 & 4.8 \\
\hline. & - & $\because$ & 35 &. & & 145 & 13 & & & \\
\hline
\end{tabular}

\begin{tabular}{|c|c|c|c|c|c|c|c|c|c|c|}
\hline \multirow{2}{*}{ 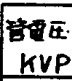 } & \multirow{2}{*}{$\begin{array}{l}\text { 時间 } \\
\text { SEC }\end{array}$} & \multirow{2}{*}{ 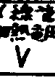 } & \multirow[b]{2}{*}{ MAS } & \multirow{2}{*}{\begin{tabular}{|c|}
$\times 2$ \\
$A L$ \\
$x_{1}$
\end{tabular}} & \multicolumn{6}{|c|}{ 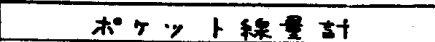 } \\
\hline & & & & & exine & 月요 & 031 & F 5 & fer立 & $M r$ \\
\hline 80 & 0.1 & 70 & 32 & 0 & -14 & 72 & 58 & & & \\
\hline - & 3 & $\cdot$ & 34 & 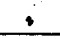 & & 132 & 60 & 58.7 & 0.38 & 22.3 \\
\hline 80.5 & 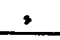 & 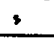 & 33 & 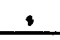 & & 194 & 58 & & & \\
\hline 81.5 & $\cdot$ & - & 31 & 0.5 & -5 & 53 & 48 & & & \\
\hline 81 & 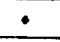 & , & 32 & $\cdot$ & & 100 & 47 & 49 & 0.38 & 18.6 \\
\hline 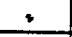 & - & $:$ & + & • & & 152 & 52 & & & \\
\hline 82 & $\cdot$ & $\div$ & 31 & 1.5 & -76 & 112 & $3 \underline{6}$ & & & \\
\hline 81 & 3 & $\cdot$ & 33 & 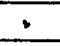 & & 145 & 33 & 35 & 0.38 & 13.3 \\
\hline$s$ & $\cdot$ & , & 31 & $\cdot$ & & 180 & 35 & & & \\
\hline$\therefore$ & $\cdot$ & 5 & 29 & 3.0 & -13 & 32 & 19 & & & \\
\hline$\cdot$ & 3 & $\cdot$ & 32 & $:$ & & 54 & 22 & 21 & 0.38 & 8.1 \\
\hline 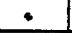 & $=$ & - & 31 & + & & 76 & 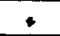 & & & \\
\hline
\end{tabular}

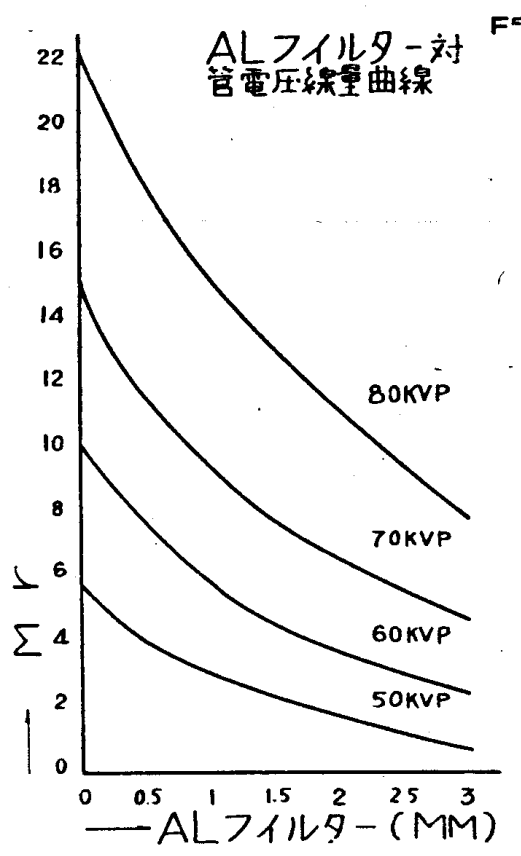

mr）より線量を換算して，如何なる管電圧においてもま た, 厚さ $1-3 \frac{m}{m}$ のフィルターを使用して, 異なった線 質の撮影う試みることができる結果を得た。

科研直読式ポケット線量計の簡易な 目盛試験法 


\begin{tabular}{|c|c|c|c|c|c|c|c|c|c|}
\hline \multirow{3}{*}{ 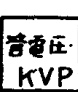 } & & & \multirow{3}{*}{ 青孚 } & & & & & PI & \multirow{3}{*}{ 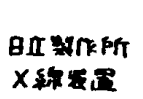 } \\
\hline & \multirow{2}{*}{$\begin{array}{l}\text { 特 } \\
\text { SEC }\end{array}$} & \multirow[b]{2}{*}{ MAS } & & \multicolumn{5}{|c|}{ 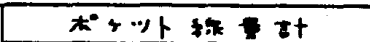 } & \\
\hline & & & & 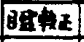 & 日酸 & $\times 31$ & $4 x \bar{y}$ & $M r$ & \\
\hline$\in C$ & CI & 6.5 & 1 & 0 & 13 & 13 & 0.36 & 4.76 & DR-10/2S \\
\hline$\cdot$ &. & $\because$ & 2 & & 30 & 17 & + & 6.2 & E结 FP肉 \\
\hline - & • & - & 3 & & 44 & 14 & $\overrightarrow{5}$ & 5.05 & $117 \mathrm{~cm}$ \\
\hline- & - & 7.0 & 4 & & 60 & 16 & 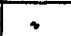 & 5.75 & 象之 \\
\hline$\cdot$ & $\cdot$ & 6.5 & 5 & & 78 & 18 & 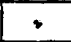 & 6.5 & トEブラフ \\
\hline- & $\cdot$ & $\therefore$ & 6 & & 94 & 16 & + & 5.75 & M50A-2㘹 \\
\hline - & - & - & 7 & & 110 & 4 & + & $\bullet$ & \\
\hline+ & 3 & $\bullet$ & 8 & & 130 & 20 & - & 7.2 & \\
\hline 5 & $\cdot$ & 6.0 & 9 & & 144 & 14 & $\bullet$ & 5.05 & \\
\hline 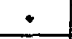 & - & 6.5 & 10 & & 162 & 12 & $\div$ & 4.32 & \\
\hline$\cdot$ & $\cdot$ & $\therefore$ & 11 & & 180 & 18 & - & 6.5 & \\
\hline 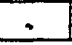 & 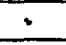 & - & 12 & & 195 & 15 & 2 & 5.4 & \\
\hline
\end{tabular}

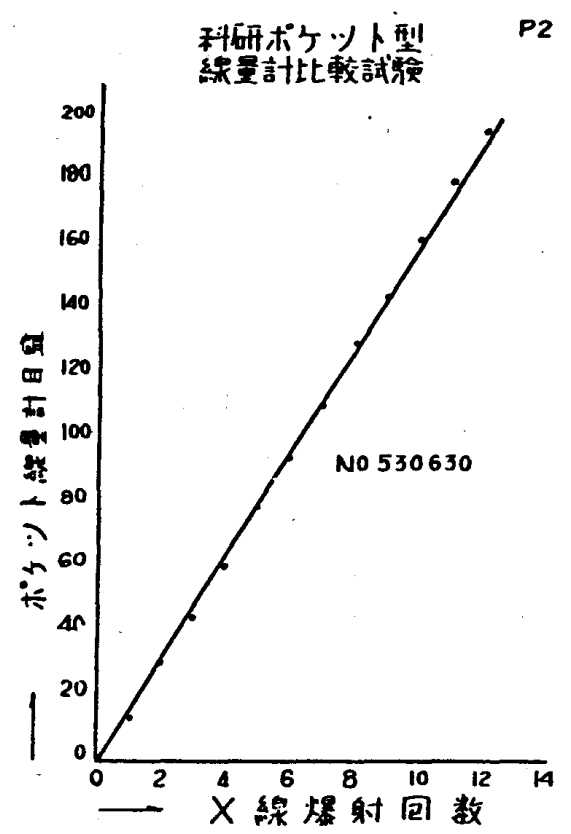

本線量計は放射線障害を防止することを目的に作製さ れたので本実験の目的には精密度などで問題がない訳で はない。しかし私が長年使用しても自然漏洩が極めて少
なく、また手許にこれに変りうろ優秀な測定器がないの で使用した。

本線量計の目盛は, 直接 $\mathrm{mr}$ で示され最大 $200 \mathrm{mr}$ まで の積算が可能である． $\mathrm{mr}$ の較正は付属の較正率表より 算出した。

線量計は平等目盛であるが各目盛がX線曝射に対し均 等を示すかを実験した結果，その目盛が $60 \mathrm{kVp}$ にわい てはば均等であると思われる。

なお線量計のX線入射方向は水平方向とした。

\section{結言}

本測定より MAS メーターに付属せる亜酸化銅整流器 の性能の少化とタイマーの誤差を発見した。

また電圧の変動により装置の性能が変ることも理解で きた。

以上X線装置にはX線管電圧図表よりも適切に性能を 示す懪射線量曲線が作られれば, 各種の装置でも同一線 量で撮影し, 同一黒化度の写真が得られるのではあるま いか. また撮影条件表に空中線量を示す $\mathrm{mr}$ が記載され るならばこれを完全に利用することができる。

なおこのような則定には標準線量計で計測して, 線量 曲線を作製すれば各装置の能能，新，旧．大，小，䒾置 の比較. 故障の有無などを簡易に検し得て利用度はさら に高く装置には不可欠となるであろうと信じます。

最後に本論文のため御助言を睗りました後藤風雲堂榎 本計重氏に厚く御礼申し上げます。

\section{考交献}

二宮，田中，片山：日放技誌第11巻第 1 号（昭30）

二宮：日放技誌特集第 1 号（昭31）

駒井，深津，小野：日放技誌特輯第 2 号（昭 $32 ）$ 